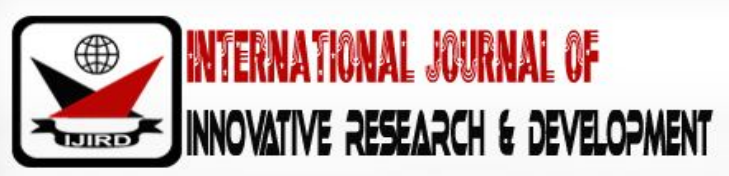

ISSN 2278 - 0211 (Online)

\section{Factors that Affect the Satisfaction of Employees in Ghana's Public Sector}

\author{
Abiel A. Armah \\ Ph.D. Candidate, Accra Institute of Technology, Ghana
}

\begin{abstract}
:
The formal definition of job satisfaction could be traced back to the studies of Fisher and Hanna in the year 1931. Based on amounts of case studies, they described job satisfaction as a product of non-regulatory mood tendency. In the year 1974, Churchill et al. published an article called Measuring the Job Satisfaction of Industrial Salesmen and made it clear that job satisfaction, as a constitutional concept, contains the features of the job and the features of job-related environment. In a positive measurement of the constitutional concept of job satisfaction, Churchill et al. gave its operational definition i.e. the work-related affection states covering five aspects namely the supervisors, jobs, work colleagues, compensation and promotion opportunities.

In summary, regardless the researchers study, the concept of job satisfaction from which perspectives their definitions of job satisfaction are derived are more or less about personal affections. If the employees have positive and pleasant feelings in work, their attitudes to the work will be defined as job satisfaction. Otherwise, if the employees have negative and unpleasant feelings in work, their attitudes to the work will be defined as unsatisfied (Yuewei Chen, 2012). In a nutshell, for the researches on job satisfaction, scholars presented different opinions from various perspectives. The development of defining job satisfaction follows a line from one single perspective to multiple perspectives.
\end{abstract}

Keywords: Satisfaction, Ghana, public sector

\section{Introduction}

Ghana's public sector employs the largest majority of workers with the objective of implementing government policies. It is the objective of government that employees in this sector are better motivated so as to achieve the goals and objectives of the government. Whereas government expects increase in productivity from the public-sector employees, the employees also are always demanding increase in salaries. Agitation from public sector workers especially those in the health and education sector have sometimes led to these workers laying down their tools for several weeks. There have been reforms from various governments with assistance from international organisations aimed at instituting measures to avert these strikes by the public-sector workers. These reforms led to the establishment of the fair-wages and salaries commission (FWSC) in 2010. The FWSC in 2010 introduced the Single Spine Salary Structure aimed at streamlining salaries in the public sector. The purpose of this paper is to examine the major intrinsic motivation factors that attract employees to the public sector, examine their level of satisfaction and analyze the relationship between job satisfaction and performance in the public sector.

\section{Review of Related Literature}

\subsection{Job Satisfaction}

Job satisfaction is associated with how people feel about their job. It is commonly defined as "how people feel about their jobs and different aspects of their jobs" (Spector, 1997, p2). Locke (1963) cited in Mafini and Dlodlo (2014) provides a more elaborate job-satisfaction definition as the positive and emotional state of an individual job resulting from an evaluation of the job. Agho, Mueller and Price (1993) also define job satisfaction as a personal evaluation of conditions present in the job or outcomes that arise as a result of having a job. Job satisfaction further relates to the extensive magnitude in which people enjoy being at their jobs, doing their work as well as being rewarded for their efforts (Hirschfield, 2000). This suggests that job satisfaction has to do with an individual's perception and evaluation of their job and this perception is influenced by unique circumstances such as needs, values and expectations (Buitendach \& De Witte, 2005). 
According to Thompson and Phua (2012), job satisfaction has to deal with the internal state of gratification or discontentment of the employees. Employees may be satisfied with their jobs based on positive experience with their fellow colleagues, nature of work, supervisors, among others (Giannikis \& Mihail, 2011). This implies that the more a person's job fulfills their personal need, the more the employee may be satisfied on the job (Yee, Yeung \& Cheng, 2010).

Oldham and Hackman (1980) posits that job satisfaction is as a result of inner motivation, therefore, could be an indicator of the psychological health of the individual. Employees who are satisfied are effective and have a positive attitude at work, thus, engage fully in work-related activities at work (Agarwal \& Ferratt, 2001). Therefore, it is important for organisations to strive to increase the level of satisfaction of their employees as this has a long term effect on the overall performance of the organisation (Price, 2001).

\subsection{Factors That Affect Job Satisfaction}

Some of determinant factors are explained in detail in the following parts. The factors are divided into two main groups: environmental factors and personal factors, according to the study of Spector (1997 cited in Reem, 2012). Environmental factors consist of working conditions, personal development opportunities, rewards, supervision, co-workers and communication. Personal factors include demographic variables which are gender, educational level and seniority.

\section{Environmental Factors}

\subsection{Working Conditions}

Working conditions consist of the physical and social conditions at work. People want to work in a safe, comfortable environment which is clean, modern and enough-equipped (Sun, 2013). They want to work in good conditions such as appropriate temperature, lighting and noise (Green, 2012). For example, people can be disturbed when they are distracted by unexpected noise such as telephones, conversations or crowding (Bridger and Brusher, 2014) and absence of temperature or lighting causes strain (MacMillan, 2012).

\subsection{Self-Improvement}

Workers want to improve their skills, abilities, knowledge and to learn new things especially those that provide personal growth. If they are satisfied with self-improvement opportunities, their overall job satisfaction level increases. Therefore, job training plays a key role for personal development opportunities and helps employees to be more specific with their job, as a result, employee job satisfaction increases. In addition, employee development programs improve workers' satisfaction level by giving them more sense of confidence, providing control over their career and increasing positive feelings towards their job (Jin and Lee, 2012).

\subsection{Reward}

According to Kalleberg (2012), reward is related with the employee's desire. It motivates employees. It shows what an employee wants after performing a certain task. According to Gerald and Dorothee (2013), rewards are very strongly correlated with job satisfaction (Javed et al., 2012). Moreover, according to related literature, rewards are divided into two categories: extrinsic rewards and intrinsic rewards. Extrinsic rewards consist of money, promotion and benefits. Intrinsic rewards include having a sense of achievement, being part of a team success, being appreciated by superiors because of a good performance and feeling recognized. Job satisfaction increases with all these feelings and returns (Başar, 2012).

\subsection{Supervision}

Employee job satisfaction is positively affected by supervisors' support and recognition of employees (Yang, et al., 2012). Since supervisors are representatives for the institution, if they are supportive and helpful, employees perceive the organization as same (Emhan, et al., 2014). Communication between supervisors and subordinates determines employees' attitudes towards their jobs. In addition, management style of supervisors is important and it can be different. For example, in one type, supervisors check employees' performance and communicate with subordinates. In another type, they allow their subordinates to participate in decisions related with their jobs (Yeltan, 2013, and Beşiktas, 2012). Lack of communication between employees and supervisors negatively affect employees' job satisfaction.

\subsection{Co-worker}

Employees that have a better relationship with their coworkers are more likely to be satisfied with their job (Yang, et al., 2012). According to Locke, employees prefer to work with friendly, supportive and cooperative people (Başar, 2012). Since people spend majority of their time with colleagues, if co-workers make them happy, this has positive impact on their job satisfaction (Beşiktas, 2012)

\subsection{Communication}

Communication within workplace is essential for organizations in terms of job satisfaction. According to Ozturk, Hancer et al. (2014), there are two different dimensions of internal communication in organizations. One of them is 
managerial communication such as giving oral presentation and giving feedback. The other one is informal interaction such as communication with each other beyond formal channels. Effective interaction and communication improve job satisfaction. On the contrary, lack of communication causes dissatisfaction.

\section{Personal Factors}

\subsection{Gender}

In literature, there are many studies investigating relationships between gender and job satisfaction. There are different results about this issue. Some of them propose that women are more satisfied than men are. Others suggest otherwise. Since men and women have different social roles, their expectancies from job may also be differ. For example, women give more importance to working conditions and social relationships whereas men are more satisfied with some factors such as pay and promotion opportunities. This may be as a result of the difference between expectancy levels of each gender in which expectancy of women are relatively lesser than men are, so, women can be satisfied with more (Beșiktas, 2012, and Spector, 2012).

\subsection{Educational Level}

In literature, most researches indicate that as the level of education increases, job satisfaction may decrease. Highly educated workers may be dissatisfied with their work if it requires performing repetitive tasks (Green, 2013). Requirements of jobs should be fitted with educational level of employee, otherwise, if educational level of a worker is so high for requirements of the job, this causes dissatisfaction (Sun, 2012). Another reason of dissatisfaction among highly educated people is to have higher levels expectation for their job.

\subsection{Work Experience}

Work experience is defined as the number of years employees have worked in an organisation. Opinions vary on the relationship between work experience and job satisfaction. Some studies state that as with age, seniority is also expected to contribute to increase of job satisfaction due to the familiarity with work content and work environment. On the other hand, some of them suggest that job satisfaction and seniority are negatively correlated as shown in De Santis and Durst's study (Green, 2012).

\section{Materials and Methods}

The quantitative method was employed in this. Structured questionnaires were designed to collect data from participants for the study. A total of 150 public servants were sampled using the systematic sampling method. Respondents were sampled from government agencies and ministries. Multiple regression was used to examine the impact of the factors on job satisfaction. The regression formula as shown in the equation below was used:

\subsection{Regression Analysis}

To examine the major determinants of job satisfaction, a regression analysis was performed. The following regression equation was used.

$\mathrm{JS}=\beta 0+\beta \mathrm{j} \mathrm{Xj}+\varepsilon$

Dependent Variable evasion.

JS= Tax evasion and for the purposes of this model penalty for not filing a tax return was used as a proxy for tax

Independent Variables factors.

$\mathrm{Xj}=$ represent the independent variables. In this study, the independent variables are the personal and environmental

$$
\varepsilon=\text { represent the error term }
$$

\section{Results and Discussion}

The sample consisted of 96 (64\%) males and 54 (36\%) females. The age distribution shows that respondents within the age group of 20-30 were $24.7 \%$, 31-40 years were $15.3 \%$ while those more than 41 years were $60 \%$. The educational level also shows that respondents with a bachelor's degree and higher accounted for $68.6 \%$ while those with less than a degree were $31.4 \%$. With respect to work experience, respondents who had worked for 1-5 were 14.7\%, 6-10 years (15.3\%) and 1120 years were $41.3 \%$. The remaining $28.6 \%$ had worked for more than 21 years in the public service in various capacities. 


\begin{tabular}{|c|c|c|c|c|c|}
\hline Variable B & Std. Error & B & t & P.value \\
\hline (Constant) & 2.856 & .015 & & 185.73 & 0.00 \\
\hline Remuneration & 2.032 & 0.010 & -0.28 & -207.74 & 0.00 \\
\hline Working conditions & 0.252 & 0.004 & -0.004 & -62.64 & 0.00 \\
\hline Relationship with workers & 6.678 & 0.018 & 1.35 & 376.14 & 0.03 \\
\hline Education & -1.162 & 0.004 & -0.29 & -272.38 & 0.02 \\
\hline Communication(supervisors) & 0.596 & 0.010 & -0.16 & -60.56 & 0.00 \\
\hline Work Experience & -3.252 & 0.006 & 0.82 & 561.69 & 0.00 \\
\hline \multicolumn{7}{|c|}{ Dependent Variable: Job Satisfaction } \\
\hline
\end{tabular}

The results in Table 2 shows positive correlation between remuneration and job satisfaction $(r=2.03 \mathrm{p}<0.05)$. There result was also statistically significance within the $5 \%$ level of significance. This demonstrates that an increase in remuneration will lead to an increase in job satisfaction level of the employee, all things being equal.

There was a positive correlation between working conditions and job satisfaction $(r=0.25, p<0.05)$. The result was also statistically significant within the $5 \%$ level of significance. This finding implies that within the public service, an improvement in working conditions of employees will lead to a corresponding increase in job satisfaction of the employees.

Relationship among coworkers is important in determining satisfaction of employee. There was a positive correlation of relationship with workers and job satisfaction $(r=6.67, p<0.05)$. This finding was also statistically significant within the $5 \%$ level of significance. This implies that when there is an improvement in relationship among coworkers, this will lead to a corresponding increase in job satisfaction among employees.

Education was negatively correlated with job satisfaction in the regression results $(r=-1.1, p<0.05)$. The result was statistically significant at the $5 \%$ level of significance. This implies that as the employees attain higher levels in their education, their job satisfaction level decreases.

The study also found a positive relationship between communication from supervisors and the employees and job satisfaction $(r=0.59, \mathrm{p}<0.05)$. The finding was also statistically significant within the $5 \%$ level of significance. This is an indication that an improvement in the way supervisors communicate with their employees will lead to a corresponding increase in job satisfaction among the employees.

Work experience had a negative relationship with job satisfaction ( $r=-3.2 . p<0.05)$. The finding was also statistically significant within the $5 \%$ level of significance. This is an indication that the longer one works at the public service the more one becomes dissatisfied.

\section{Discussion of Findings}

This study has examined the determinants of job satisfaction among public servants. It found a strong and positive relationship between remuneration and job satisfaction. This finding corroborates earlier empirical studies by Mafini and Dlodlo (2014). According to Gerald and Dorothee (2013), rewards are very strongly correlated with job satisfaction. This means that employees are motivated to work when they are remunerated well. Lewis and Frank (2004) found a strong and positive correlation between remuneration and satisfaction. Working conditions of the employee are important if employees are to be satisfied and work well.

The study also found working conditions to be a predictor of job satisfaction. Job conditions include the use of inputs required by the employee at the work place. This means that when the conditions of work are improved, the employees will be satisfied and work well. Relationship with co-workers is also important in determining the level of satisfaction of employees.

The study's findings revealed a positive relationship between co-worker relationship and satisfaction. This implies that employees need to work in a cordial environment with their colleagues so as to be satisfied. With respect to education, there was a negative relationship although a weak predictor. This might be due to the fact that when employees attain higher levels of education without a corresponding increase in remuneration, dissatisfaction may set in. Also, when they perform repetitive work, dissatisfaction may set in (Green, 2013).

The level of communication from supervisors is important in determining job satisfaction of employees. When supervisors relate well with their employees in a cordial manner, there is the possibility that they will be happy and give out their best. This finding corroborates the study by Mafini and Dlodlo (2014) who also found a positive relationship between supervision and satisfaction.

\section{References}

i. Accel (2010). Employee Motivation, available at: http// www.accelteam.com/ motivation/ intro.html, retrieved 201612-29. Retrieved 122016.

ii. Ahlstrom, D., \& Bruton, G. D. (2013). International Management:Strategy and Culture in Emerging World. SouthWestern Cengage Learning. 
iii. $\quad$ Anderfuhren-Biget, E. A. (2013). Motivating Employees of the Public Sector: Does Public Service Motivation Matter? a paper presented at IRSPM Conference, (p. 20). Bern.

iv. Anupam, D. (2014). Impact of Motivation Strategies on Employee Performance: A Comparative Study of Two Hotels in Canada and Saudi Arabia. Proceedings of 11th Asian Business Research Conference 26-27 December' 2014. Dhaka, Bangladesh: BIAM Foundation.

v. Attrams, R. (2013). Motivation and Employee Satisfaction: Perceptions of Workers in Public and Private Health Care Facilities. . M.Phil. Thesis, University of Ghana, Legon.

vi. Bowey, A. (2012). Motivation: The Art of Putting Theory into Practice. Business Forum(20), 17-20.

vii. Brayfield, A. H. (1955). Employee attitudes and employee performance. Retrieved from http:/ / dx.doi.org/ 10.1037/ h0045899.

viii. Bridger, R. S. (2014). Cognitive Task Demands, Self-Control Demands and the Mental Well-Being of Office Workers. Ergonomics . doi:10.1080/ 00140139.2011.596948

ix. Bright, L. (2009). Why Do Public Employees Desire Intrinsic Nonmonetary Opportunities? In Public Personnel Management (Vol. 38, pp. 15-37).

x. $\quad$ Brooks-Immel, D. R. (2014). "A Comparative Study of Public Service Motivation among Organizational Units in a Public University". Doctoral Dissertations.

xi. Buelens, M.(2007). An Analysis of Differences in Work Motivation between Public and Private Sector Organizations, Vol. , , p.. Public Administration Review, 67, 65-74.

xii. Christensen, P. (2013). Motivational strategies for public managers: The budgetary belt-tightening precipitated by the recession has placed renewed emphasis on the importance of employee motivation, Government Finance Review: http. Retrieved from http:/ / findarticles.com/ p/ articles/mi_hb6642/ is_2_18/ai_n28910543/ ?tag=content;col.

xiii. Dunford, R. W. (2012). Organizational Behaviour: An Organizational Analysis Perspective. Addison-Wesley Business Series.

xiv. Durant. (2012). Motivating employees in a new governance era: The performance paradigm.

xv. Greenberg, P. (2012). Behaviour in Organization (8th ed.). Bloomsbury UK: Prentice-Hall. GILLHAM B (2013), Research Interview.

xvi. $\quad$ Herzberg, F. ( 2003 ). One More Time: How Do You Motivate Employees?

xvii. Ireland, P. A. (2012). Challenge and change in the Irish Public Service in 2010,. Conference on Morale, motivation, transformation and service delivery in the public sector . Dublin. Retrieved March 24, 2012, from www.puplicaffairsireland.com/ conferences/ details/ ?ID $=643$

xviii. Iyengar, S., \& Lepper, M. (2012). When Choice is Demotivating: Can One Desire Too Much of a Good Thing. Journal of Personality and Social Psychology.

xix. Jin, M. H. (2012). The Effects of Autonomy, Experience, and Person-Organization Fit on Job Satisfaction. The Case of Public Sector. The International Journal of Social Sciences, 6(1), 18-44.

xx. Jurkiewicz, L., \& Massey, G. (2012). Motivation in Public and Private Organizations: A Comparative Study, Public Productivity \& Management Review. M.E Sharpe, Inc.

xxi. Kaiser, C. L. (2014). Job Satisfaction and Public Service Motivation. . North Rhine-Westphalia University of Applied Sciences for Public Administration.

xxii. Landy, J., \& Conte, M. (2012). Work in the 21st Century: An introduction to industrial and organizational psychology (3rd ed.). McGraw Hill.

xxiii. Locke, E. A. (n.d.). Building a Practically Useful Theory of Goal Setting and Task Motivation: A 35-Year Odyssey, American Psychologist.

xxiv. $\quad$ MANforum. (2012). It's Always About The Boss. THE MAN GROUP MAGAZINE.

xxv. Maslow, A. H. (1943). A Theory of Human Motivation , Psychological Review. Retrieved from http:/ / psychclassics.yorku.ca/ Maslow/ motivation.htm, retrieved 2010-05-25.

xxvi. $\quad$ Miner, J. B. (2012). Organizational Behavior 1: Essential Theories of Motivation and Leadership.

xxvii. Mitchell, T. R. (2012). Motivation: New Directions for Theory, Research, and Practice. The Academy of Management Review, 7, pp. 80-88.

xxviii. Paarlberg, E.A (2012). Theory to Practice: Strategies for Applying Public Service Motivation. In J.L. Perry (Ed.), Motivation in Public Management: the Call of Public Service (pp. 268-293). Oxford University Press.

xxix. Perry, J. \&. (2012). Motivation in Public Management: the Call of Public Service. Oxford University Press.

xxx. Petrovsky, N. (2013). Public service motivation and performance: a critical perspective. Retrieved June 4th, 2016, from http:/ / www www.emeraldinsight.com/ 2049-3983.htm

xxxi. Rainey, H. G. (2012). Work Motivation, Handbook of Organizational Behavior. (R. Golembiewski, Ed.) Marcel Dekker. xxxii. Rainey, H. G. (2012). Work Motivation, Handbook of Organizational Behavior. (R. Golembiewski, Ed.) Marcel Dekker. xxxiii. Robbins, S. P. (2012). Organizational Behavior (13 ed.). Prentice-Hall.

xxxiv. Robbins, S. P. (2012). Organizational Behavior (13 ed. Prentice-Hall.

xxxv. Robbison, S. P., \& Judge, A. (2013). Disengagement Can Be Really Depressing. http:/ / gmj.gallup.com/ content/ 127100/ disengagement-really-depressing.aspx(2010-04-02). 
xxxvi. Robison, S. \&. (2013). Disengagement Can Be Really Depressing. Gallup Management Journal website. Retrieved 42 , 2010, from http:/ / gmj.gallup.com/ content/ 127100/ disengagement-really-depressing.aspx

xxxvii. Schwartz, B. (2004). The Tyranny of Choice, Scientific American Magazine.

xxxviii. Taylor, J. \&. (2011). “Working Hard for More Money or Working Hard To Make a Difference? . In Efficiency Wages, Public Service Motivation, and Effort." Review of Public Personnel Administration, (pp. 67-86,31(1)).

xxxix. Van Loon, M. N. (2015). The Role of Public Service Motivation in Performance. Examining the potentials and pitfalls through an institutional approach. Unpublished PhD Dissertation.

xl. Van Wart, M. (2012). Leadership in Public Organizations: An Introduction, M.E. Sharpe.

xli. Vandenabeele, W. (2012). Toward a Public Administration Theory of Public Service (Vol. 9).

xlii. Watson, T. J. (1986). Management, Organization, and Employment Strategy. New Directions in Theory and Practice.

xliii. Weibel, A. R. K., \& Osterloh, M. (2010). Pay for Performance in the Public Sector- Benefits and (Hidden) Cost (Vol. 20). Journal of Public Administration Research and Theory.

xliv. Wright, B. E. (2001). Public Sector Work Motivation: Review of Current Literature and a Revised Conceptual Model. Journal of Public Administration Research and Theory, 1, 556-586.

xlv. Zikmund, W. (2007). Business Research Methods: .Essentials of Marketing Research. USA, Thompson South-Western 